DOI: https://doi.org/10.31392/NZ-npu-144.2019.16

УДК 327:351.746.1(477)

Мартіросян О. І., Порошина В. Д., Купрій Т. Г.

\title{
УКРАЇНСЬКА ДЕРЖАВА \\ В СУЧАСНОМУ ГЕОПОЛІТИЧНОМУ ПРОСТОРІ: НАЦІОНАЛЬНА БЕЗПЕКА ТА ПРОБЛЕМИ ЄДНОСТІ
}

\author{
Гідність держави залежить, \\ в кінцевому рахунку, від гідності \\ особистостей і освіченості націі, \\ які ї̈ утворюють.
}

Д. Мілль

На підставі історико-політологічних джерел та історичних фактів у статті проаналізовані шляхи перебудови і реформаиї української держави в сучасному геополітичному просторі.

Аналізуючи дефініиії і визначення дослідників різних історичних періодів автори дійшли до висновку, що стратегічна і сьогодення мета намої держави для збереження кордонів, полягає в інтеграмії до європейських та євроатлантичних структур.

Саме иее буде запорукою побудови правової держави в складних умовах національного державотворення.

Ключові слова: європейські держави, науковий потенціал, стратегія освіти, геополітичний простір, правова держава

Кінець XX століття для історії європейських держав постає з суттєвими геополітичними змінами. Новою політичною реальністю кінця $\mathrm{XX}$ століття стало створення Української незалежної держави (1991р.), яка вийшла з поміж інших держав пострадянського простору.

Виваженість зовнішньої політики, її миролюбні засади, конструктивний але добрий, дійовий і реформаторський характер суспільних перетворень підвищили рівень безпеки для нашої держави на європейському континенті. Всі ці чинники, ще в далекі 90-ті роки XX ст., закріпили європейську сім'ю народів з Україною, яку стали ще більше поважати і рахуватися з нею. Тому процес становлення в Україні громадянського суспільства і майбутньої правової держави може вважатися однією з основних проблем в процесі українського державотворення та в умовах фрормування нової ідеології, нової соціальної структури. За визначенням американського політолога польського походження 3. Бжезинського: “... незалежна Україна створила можливості для самої Росії, нарешті, стати демократичною і європейською...”.

Стратегічна і сьогоденна мета нашої держави полягає в інтеграції до європейських та євроатлантичних структур, це буде для нас запорукою, щоб східна сусідка-агресор не зазіхала на наші території і земні багатства.

Американський політик і вчений Д. Мойніхен вважає, що “... небажання слов'янської України продовжувати жити в тоталітарному режимі "під тиском Кремля”, є найсуттєвішим чинником розвалу Радянського Союзу”. Україна має 
невичерпні надра Карпат і Криму, най родючіші землі чорнозему в Європі, могутній виробничий, науковий, освітній, культурно-мистецький, кадровий потенціал. Але конкретних, соціально-правових, державних засобів організації і реформації суспільства в нас ще не визначено. Тому перед президентом, прем'єр-міністром, парламентом, радою міністрів і політичною елітою постало нагальне завдання, нарешті, чітко і конкретно, визначити і реалізувати державну стратегію розвитку і збереження країни.

Зараз на нашій території іде війна, сусідка-агресор Росія захопила наші території. Ми не змогли мобілізуватися, дати одразу відсіч, тому треба називати речі своїми іменами, ми проґавили Крим, Донбас. Враховуючи труднощі сьогодення незалежна і суверенна Україна, яка перебуває на перехресті стратегічних інтересів великих держав, живе у складній геополітичній ситуації. Україна повинна бути дипломатичною, конкретною, обережною, вона повинна керуватись концепцією "динамічної рівноваги сил", яка орієнтує українську державу на забезпечення умов для фрормування та розвитку відносин як з європейськими країнами так із країнами Балтії, Білорусією, Грузією, Вірменією, Азербайджаном, Казахстаном, Молдовою.

Український народ вимагає від свого уряду певних дій гідності, порядку, правди, справедливості, грошової стабільності, соціального захисту. Українська держава ще молода, тому ми проходимо сценарій соціальносуспільних змін, які вже пройшли незалежні східноєвропейські держави, ми запозичуємо досвід державних аналітичних моделей і концепцій історичної соціології демократичних інституцій, про які писали Р. Дарендорф, А. Турен, У. Пальме, М. Вебер, С. Роксана, Е. Гелнер, Д. Дюркгейм, К. Гельвецій, Ю. Габермас, Л. Екман. Усі європейські країни і Україна, в тому числі, проходять певні етапи розвитку виявляють універсальні соціокультурні закономірності на цьому шляху. Цими закономірностями були процеси модернізації, демократизації, економічні реформи, науково-технічні здобутки, реформування грошової системи, формування громадянського суспільства і стандартів прав людини, які відбувалися в Західній Європі впродовж XVIIXX ст.

I, нарешті, вже в XXI ст. Україна, вивчаючи історико-дипломатичний досвід і користуючись відомими моделями соціологічної глобалістики країн Євросоюзу, вибудовує свою рідну національну державність з відповідними пріоритетами національно-культурного відродження. Для соціального переструктурування українського суспільства це означало болісну психологічну перебудову переважної частини населення, від стереотипів радянського тоталітаризму і прийняття зразків західноєвропейського демократизму, консерватизму, лібералізму, плюралізму, державності, що допомагають українському суспільству толерантно співіснувати в соціальнополітичних процесах кінця XX ст. і початку XXI ст. Цитата з духовної книги: “... оскільки знедолені члени суспільства не можуть, як інші, працювати, захищати своє життя і здоров'я, захищати свої права, держава зобов'язана взяти на себе особливу відповідальність і допомагати їм усім..." [7, с. 9]. 
Несправедливість, неправда злочинної влади в Україні різних періодів стала головною причиною Помаранчевої революції. Політична еліта першого покоління, все ще лишається впливовою, вони живуть “для себе", вони в постійній боротьбі за власні вигоди і особисто партійні амбіції. Саме цією владою та їх прихильниками були порушені духовні закони побудови відносин у суспільстві - вимоги, встановлені Богом, внаслідок чого спрацювала визначена Богом закономірність - люди повстали, щоб захистити себе і сім'ї від свавілля, люди повстали для знищення неправдивої, несправедливої влади. Ця думка прозвучала і у новорічному вітанні з 2005 р. Голови Верховної Ради України В. Литвина: “... революція, що відбувалася була моральною. Люди вийшли на вулицю за правдою і свободою...”.

Визнання Європейським Союзом важливого значення України у фрормуванні нової архітектури європейської безпеки в третьому тисячолітті повинно бути використано як суттєвий важіль позитивного просування, ствердження і визнання українських інтересів у відносинах з ЄС.

Україна прагне стати активним суб'єктом і партнером ЄС, який фрормує геополітичний простір навколо своїх кордонів, але при цьому Україна із-за воєнних агресорських амбіцій Росії залишається пасивним і нерішучим об'єктом масштабних процесів у міжнародних відносинах.

Із-за порушення Мінських угод і невиконання Росією багатьох пунктів цієї угоди, Україна може стати заручником або Сходу або Заходу, а ще гірше розмінною монетою в геополітичних іграх великих держав.

Належність України до Європи визначається не тільки географрічними, а й історичними і культурними чинниками. Сучасна Україна - засновниця i спадкоємиця Київської Русі, країна перших слов'янських князівств, країна, яка перша прийняла християнство, країна братських шкіл, колегіумів, університетів. Київ вважався третім за величиною містом після Константинополя і Кордови. Володарі Франції і Швеції, Угорщини і Польщі, Візантії та Англії, Німеччини і Норвегії вважали для себе за честь поріднитися 3 великими київськими князями. 3 цього приводу історик М.С. Грушевський вважав, що стержнем української ідеї було невід'ємне право на самовизначення i пошук. М.С.Грушевський наголошував “... наш край великий і багатий, один з найкращих країв у світі, створений для розвитку великої економічно сильної держави".

Помаранчева революція замінила, в той час, управлінську еліту і важливо те, що революція повністю змінила і об'єднала вже давно свідомий і розумний народ. Ми змінили свою історію, українська нація стала мудрою, ми бачимо своє майбутнє, ми знаємо нашу мету. Українське суспільство має державну гідність, тому ми більше не $є$ посткомуністичним, пострадянським, постгеноцидним простором. В цьому позитивне значення нашого Першого Майдану.

Але наша українська держава, яка поважає всі нації і народності, стомилася вже воювати. Ми всі потребуємо взаєморозуміння, любові, поваги, справедливості і гідності в бізнесі і редрормах, душевної доброти, людської довіри. Ми всі, увесь наш народ, представники всіх верств населення, 
управлінці і парламентарії, повинні зібратися духом, розумом, силою і, нарешті, вирішити, як ми будемо будувати свою державу, щоб в ній щасливо i спокійно жили наші діти, онуки і правнуки.

Відомий історик, громадський діяч, політолог В. Липинський наголошував: “... ніхто не збудує держави, коли ми самі їі не збудуємо, і ніхто з нас не зробить нації, коли ми самі нацією не хочемо бути".

Сучасне українське суспільство $€$ модерним, демократичним, індустріальним 3 аграрними і постіндустріальними чинниками, але $\epsilon$ поляризованим, не зовсім відкритим світові. Маючи 90 \% населення з доволі високим освітнім рівнем, українці характеризуються низьким рівнем впевненості в своїй державі і в національному майбутті. Наше суспільство має спільний духовний стержень але, іноді, ми втрачаємо віру у можливості побудови цивілізованої української демократичної держави тому, що 83 \% українського населення живуть за межею бідності. Всім нам, українцям і громадянам України, треба було проводити люстрацію корупціонерів починаючи з 1991 р., бо стара корумпована бюрократія затаїлася, утвердилася, зміцнилася своїми відповідними законами і продовжує своє життя і збагачення за рахунок кримінальних схем.

Нова владна еліта, яку ми обираємо для державотворчих i загальноцивілізаційних життєвих процесів є нерішучою, малопридатною, корумпованою, ненадійною, не професійною до рішучих демократичних змін. Всі вони з часом сформуються в панівну, не прогресивну, корумповану, відірвану від суспільства і свого народу меншість.

\section{Поговоримо про середній клас.}

Середній клас, як фрактор становлення громадянського суспільства в Україні не був гарантом стабільності і надійності. I як зазначає професор О. С. Александрова: “... через свою нечисельність він не міг стати стабілізуючою силою, його потенціалу вистачало лише для того, щоб дати поштовх прогресивним зрушенням у суспільстві, а потім через власну слабкість у процесі суспільних змін він розчиняється в соціальному просторі".

Соціально-економічні та ідеолого-політичні протиріччя породжують в українському суспільстві непередбачуваність подій та неадекватну поведінку більшості людей в умовах нестабільності. Історично склалося так, що наш український народ постійно веде перманентну боротьбу проти чужого, окупаційного політичного режиму. Невже у нас, у українців, немає політичної волі і бажання, нарешті, встановити на своїй землі справедливі закони і обрати віддану своїй державі владу.

Ми маємо величезний національний досвід, який гартувався в підпіллі, катаклізмах, дисидентстві, засланні, повстаннях, мітингах і барикадах. У нашому суспільстві давно існує попит на кваліфіковану команду патріотів управлінців, підприємців, бізнесменів, в ієрархії цінностей яких домінують національні пріоритети, ідея, шляхетність, мораль, порядність, а не меркантильні інстинкти хижацького накопичення капіталу. На сьогодні, українське суспільство, дуже поляризоване, так наприклад, українська 
інтелігенція хотіла 6 реалізувати свої знання, досвід, сорормувати своє благополуччя, накопичити свій особистий капітал, відчувати себе гідною людиною, але всі ці інтелектуальні намагання штучно гальмуються державною економічною політикою. Замість порядних людей, на арену суспільства "вилазять" корумповані управлінці, чиновництво, керівники державних господарських управлінь, які зловживають своїм службовим становищем, які заставляють нашу молодь обслуговувати клас багатих. Тому недостатність суспільних інтегруючих основ, слабка здатність суспільства до самореалізації привели до того, що в сучасних умовах економічної і політичної кризи народ України демонструє разючу безпорадність. Із-за воєнної напруги, соціальної несправедливості у нашому суспільстві відсутній базовий соціальний консенсус, існує надлом соціального поля, який надає розлад і непорозуміння між певними соціальними групами. Можна наголосити, що в процесі демократичних перетворень нам заважає "недорозвинутість" політичної культури суспільства, яка не відповідає сучасним вимогам і $€$ великою перешкодою на шляху до цивілізованого розвитку української держави.

Парламентарі, президент, міністри, державні управлінці повинні усвідомлювати, що ми їх обрали, щоб вони були “помічниками і слугами народу", а не "місцевими князьками" і “володарями світу". Надана їм влада повинна використовуватися для суспільного добра i блага, для державотворчих процесів, для консолідації всіх верств громадян, для змістовної національної освіти, для збереження життя і здоров'я нації, а не для власного збагачення і таємного накопичення капіталу і приватної власності. Відомий дослідник і історик В. Янів у своїй ґрунтовній праці “Нариси до історії української етнопсихології” (Мюнхен, 1993) писав: “...держава виникає там, де $\epsilon$ динаміка духу, сильно розвинута воля, яка зуміє силою поєднати змагання сильних індивідуальностей, що розходяться, як у Європі, або там, де пасивне, байдуже суспільство, що не вміє протиставитися деспотові і підкоряється йому, як у Азії. Ми, вже належачи, в основному до Європи, занадто відхилися від неї, щоби викресати в собі достатньо волі, конче потрібної для побудови держави, однак і не наблизилися настільки до Азії, щоби дати себе вести власному деспотові....".

Підсумовуючи історико-соціологічні аспекти сучасних змін у суспільнополітичному житті сучасної України, ми звертаємося до висновків і концепцій історичної соціології, враховуючи геополітичний досвід трансформаційних процесів в країнах Європи та імперські домагання Росії, ми історично підтверджуємо, що Україна, як і більшість країн європейської цивілізації, за останні 30 років, пройшла 4 стадії ситуацій суспільної конфліктності:

- династійно-ієрархічна боротьба за владу;

- класова боротьба за перерозподіл капіталу і здобутків індустріалізму;

- національно-культурні змагання за незалежність;

- виборювання національної ідеї та побудови і майбутньому громадянського суспільства.

Підсумовуючи вище сказане, наводимо як приклад тлумачення відомого 
американського політолога, професора Каліфорнійського університету Девіда Істона. У своїх працях "Політична система" та "Системний аналіз політичного життя” він наголошує: “... Кожна нація творить власну історію. Влада виступає від імені всього суспільства і має “публічну" основу своєї діяльності, тому інтеграція соціуму - це єдність народу і його внутрішніх взаємозв'язків. Ці взаємозв'язки породжують кількісне і якісне зростання солідарності та сприяють зростанню суспільної довіри і демократії ...”.

\section{Використана література:}

1. Андрущенко В. П. Організоване суспільство. Проблеми організації та суспільної самоорганізації в Україні на рубежі століть: досвід соціально-філософського аналізу. Київ : Атлант ЮЕмСІ, 2005. 488 с.

2. Бурковський I., Немиря Г., Павлик О. Україна і європейська інтеграція. Дорога в майбутнє дорога в Європу. Київ, 2000.

3. Валевський О. Л., Гончар М. М. Структура геополітичних інтересів України. Наиіон. інс-m стратегічних досліджень : наук. допов. 1995. Вип. № 45.

4. Врублевський В., Хорошковський В. Український шлях. Начерки: геополітичне становище України та їі національні інтереси. Київ, 1997.

5. Гаврилишин Б. Время глобализации: сценарии для Украины и России - угрозы и шансы. День. 2001. 11 апреля.

6. Гуцал А. На пороге нового тысячелетия: Куда дрейфует мир? Зеркало недели. 2000. 15 января.

7. Дергачов О. Україна в європейському і євразійському інтер’єрі. Політична думка. 2000. № 4.

8. Державна програма співробітництва України з Організацією Північно-Атлантичного договору (НАТО) на 2001-2004 роки: Затверджена Указом Президента України від 28.01.01 № 58/2001.

9. Дощюк С., Грановский В. Что будет делать Украина в XXI веке? Способна ли отечественная элита сформулировать государственную стратегию? День. 1999. 11 февраля.

10. Європейський Союз і Україна: через зміцнення зв'язків до інтеграції : матеріали Міжнародної конференції; Київ, 1-2 жовтня 1999 р. - К.: Інститут Схід-Захід (Київський центр).

11. Кавун О. В., Мартіросян О. І. Модернізація українського суспільства та розробка шляхів побудови громадянської держави як основи демократичних цінностей. Наукові записки: [збірник наукових статей] / Мін-во освіти і науки України, Нац. унів-т ім. М. П. Драгоманова ; укл. Л. Л. Макаренко. Київ : Вид-во НПУ ім. М. П. Драгоманова, 2014. Вип. СХХ (120). Серія “Педагогічні та історичні науки". 290 с. С. 50-57.

12. Кавун О. В., Мартіросян О. І.ЦЦінності демократичного соціалізму та еволюція політичних поглядів української і західної соціал-демократії у другій половині XX століття . Наукові записки : збірник наукових статей / Мін-во освіти і науки України, Нац. унів-т ім. М.П. Драгоманова ; укл. Л.Л.Макаренко. Київ : Вид-во НПУ ім. М.П.Драгоманова, 2014. Вип. СXIX (119). Серія "Педагогічні та історичні науки". 265 с. С. 89-94.

13. Колодій А. Ф. На шляху до громадянського суспільства. Теоретичні засади й соціокультурні передумови демократичної трансформації в Україні : монографія. Львів : Вид-во "Червона калина", 2002. 272 с.

14. Кремень Т. В. Політична мобілізація в соціально-медійному вимірі : монографія / Національний університет ім. Т.Г. Шевченка. Київ : Грамота, 2013. 256 с.

15. Мартіросян О. І. Якості та роль політичного лідера в Україні: соціокультурні умови та демократичні трансформації. Аналітика $i$ влада: журнал експертно-аналітичних матеріалів $i$ наукових проблем / Інститут проблем державного управління. Київ, 2012. С. 81-83.

16. Михальченко М. І. Україна як нова історична реальність: запасний гравець Європи. Дрогобич : ВФ “Відродження”, 2004. 488 с.

17. Нагорний В. Сутнісні проблеми політичної культури України. Політичний менеджмент. Київ : 2006. № 5 (72).

18. Олійник О. Міжнародний імідж України як дзеркало внутрішнього життя. Урядовий кур'єр. 2000. 16 травня. С. 16.

19. Розумний М. М. Суспільні ідеї як чинник формування політичної нації: дисертація на здобуття наукового ступеня доктора політичних наук / М. М. Розумний. Київ, 2007. 
20. Степаненко В. Глобальное гражданское общество: концептуализации и посткоммунистические вариации. Социология: теория, методы, маркетинг. 2005. № 2.

21. Шестопал Е. Б. Личность и политика. Критический очерк современных западных концепций политической социализации. Москва, 1998.

22. Щедрова Г. П. Громадянське суспільство як передумова створення динамічної політичної системи. Політична система сучасної Украӥни: особливості становлення, тендениї розвитку / редкол. : Ф. Ф. Рудич (голова) та ін. Київ, 1998.

\section{References:}

[1] Andrushchenko V. P. Orhanizovane suspilstvo. Problemy orhanizatsii ta suspilnoi samoorhanizatsii v Ukraini na rubezhi stolit: dosvid sotsialno-filosofskoho analizu. Kyiv : Atlant YuEmSI, 2005. 488 s.

[2] Burkovskyi I., Nemyria H., Pavlyk O. Ukraina i yevropeiska intehratsiia. Doroha v maibutnie - doroha v Yevropu. Kyiv, 2000.

[3] Valevskyi O. L., Honchar M. M. Struktura heopolitychnykh interesiv Ukrainy. Natsion. ins-t stratehichnykh doslidzhen : nauk. dopov. 1995. Vyp. № 45.

[4] Vrublevskyi V., Khoroshkovskyi V. Ukrainskyi shliakh. Nacherky: heopolitychne stanovyshche Ukrainy ta yii natsionalni interesy. Kyiv, 1997.

[5] Gavrilishin B. Vremya globalizacii: scenarii dlya Ukrainy i Rossii - ugrozy i shansy. Den. 2001. 11 aprelya.

[6] Gucal A. Na poroge novogo tysyacheletiya: Kuda drejfuet mir? Zerkalo nedeli. 2000. 15 yanvarya.

[7] Derhachov O. Ukraina v yevropeiskomu i yevraziiskomu interieri. Politychna dumka. 2000. № 4.

[8] Derzhavna prohrama spivrobitnytstva Ukrainy z Orhanizatsiieiu Pivnichno-Atlantychnoho dohovoru (NATO) na 2001-2004 roky: Zatverdzhena Ukazom Prezydenta Ukrainy vid 28.01.01 № 58/2001.

[9] Doshyuk S., Granovskij V. Chto budet delat Ukraina v HHI veke? Sposobna li otechestvennaya elita sformulirovat gosudarstvennuyu strategiyu? Den. 1999. 11 fevralya.

[10] Ievropeiskyi Soiuz $i$ Ukraina: cherez zmitsnennia zviazkiv do intehratsii : materialy Mizhnarodnoi konferentsii; Kyiv, 1-2 zhovtnia 1999 r. Kyiv : Instytut Skhid-Zakhid (Kyivskyi tsentr).

[11] Kavun O. V., Martirosian O. I. Modernizatsiia ukrainskoho suspilstva ta rozrobka shliakhiv pobudovy hromadianskoi derzhavy yak osnovy demokratychnykh tsinnostei. Naukovi zapysky: [zbirnyk naukovykh statei] / Min-vo osvity i nauky Ukrainy, Nats. univ-t im. M. P. Drahomanova ; ukl. L. L. Makarenko. Kyiv : Vyd-vo NPU im. M. P. Drahomanova, 2014. Vyp. SKhKh (120). Seriia "Pedahohichni ta istorychni nauky". 290 s. S. 50-57.

[12] Kavun O. V., Martirosian O. I. Tsinnosti demokratychnoho sotsializmu ta evoliutsiia politychnykh pohliadiv ukrainskoi i zakhidnoi sotsial-demokratii u druhii polovyni KhKh stolittia. Naukovi zapysky : zbirnyk naukovykh statei / Min-vo osvity i nauky Ukrainy, Nats. univ-t im. M.P. Drahomanova ; ukl. L. L. Makarenko. Kyiv : Vyd-vo NPU im. M. P. Drahomanova, 2014. Vyp. SKhIKh (119). Seriia "Pedahohichni ta istorychni nauky". 265 s. S. 89-94.

[13] Kolodii A. F. Na shliakhu do hromadianskoho suspilstva. Teoretychni zasady y sotsiokulturni peredumovy demokratychnoi transformatsii v Ukraini : monohrafiia. Lviv : Vyd-vo "Chervona kalyna", 2002. 272 s.

[14] Kremen T. V. Politychna mobilizatsiia v sotsialno-mediinomu vymiri : monohrafiia / Natsionalnyi universytet im. T. H. Shevchenka. Kyiv : Hramota, 2013. $256 \mathrm{~s}$.

[15] Martirosian O. I. Yakosti ta rol politychnoho lidera v Ukraini: sotsiokulturni umovy ta demokratychni transformatsii. Analityka $i$ vlada: zhurnal ekspertno-analitychnykh materialiv i naukovykh problem / Instytut problem derzhavnoho upravlinnia. Kyiv, 2012. S. 81-83.

[16] Mykhalchenko M. I. Ukraina yak nova istorychna realnist: zapasnyi hravets Yevropy. Drohobych : VF "Vidrodzhennia", 2004. $488 \mathrm{~s}$.

[17] Nahornyi V. Sutnisni problemy politychnoi kultury Ukrainy. Politychnyi menedzhment. Kyiv : 2006. № 5 (72).

[18] Oliinyk O. Mizhnarodnyi imidzh Ukrainy yak dzerkalo vnutrishnoho zhyttia. Uriadovyi kurier. 2000. 16 travnia. S. 16.

[19] Rozumnyi M. M. Suspilni idei yak chynnyk formuvannia politychnoi natsii: dysertatsiia na zdobuttia naukovoho stupenia doktora politychnykh nauk / M. M. Rozumnyi. Kyiv, 2007.

[20] Stepanenko V. Globalnoe grazhdanskoe obshestvo: konceptualizacii i postkommunisticheskie variacii. Sociologiya: teoriya, metody, marketing. 2005. № 2.

[21] Shestopal E. B. Lichnost i politika. Kriticheskij ocherk sovremennyh zapadnyh koncepcij politicheskoj socializacii. Moskva, 1998. 
[22] Shchedrova H. P. Hromadianske suspilstvo yak peredumova stvorennia dynamichnoi politychnoi systemy. Politychna systema suchasnoi Ukrainy: osoblyvosti stanovlennia, tendentsii rozvytku / redkol. : F. F. Rudych (holova) ta in. Kyiv, 1998.

МАРТИРОСЯН Е. И., ПОРОШИНА В.Д., КУПРИЙ Т. Г. Украинское государство в современном геополитическом пространстве: национальная безопасность и проблемы единства.

На основании историко-политологических источников и исторических фактов в статье проанализированы этапы перестройки и реформащии украинского государства в современном геополитическом пространстве.

Анализируя дефиниции и определения исследователей разных исторических периодов, авторы пришли к заключению, что стратегическая и современная цель нашего государства состоит в сохранении грании и суверенитета и в дальнеймей интеграции к европейским и евроатлантическим структурам.

Именно вхождение Украины в европейский союз будет гарантией для построения правового государства и утверждения национальной независимости.

Ключевые слова: европейские государства, научный потенціал, стратегия образования, геополитическое пространство, правовое государство.

Martyrosian E. I., Poroshyna V. D., Kupryi T. H. The Ukrainian state is in modern geopolitical space: national safety and problems of unity.

On the basis of political историко-политологических sources and historical facts in the article the stages of alteration and reformation of the Ukrainian state are analysed in modern geopolitical space.

Analysing definitions and determinations of researchers of different historical periods, authors came to the conclusion, that the strategic and modern aim of our state consists of maintenance of borders and sovereignty and in further integration to the European and евроатлантическим structures.

Exactly the included of Ukraine in the European union will be a guarantee for the construction of the legal state and claim of national independence.

Keywords: the European states, scientific nотениiar, strategy of education, geopolitical space, legal state.

DOI: https://doi.org/10.31392/NZ-npu-144.2019.17

УДК 37.091.33:78-053.6

Пань Цяньї

\section{МЕТОДИ ДІАГНОСТИКИ ВИХІДНОГО РІВНЯ КРЕАТИВНОСТІ УЧНІВ-ПІДЛІТКІВ У НАВЧАЛЬНО-МУЗИЧНІЙ ДІЯЛЬНОСТІ}

В статті розглядається методика діагностики початкового рівня розвитку креативності учнів підлітків у навчально-музичній діяльності. У констатувальному експерименті було використані методи спостережкення, анкетування і тестування, метод створення підлітками особистих творчих продуктів. Автор статті пропонує методи діагностики, ще містять ситуаиії реального вибору; ситуаиії вибору навчальних завдань різного рівня; ситуаиії вибору за певними критеріями; ситуації вибору навчальної мети, яка диференціюється за ступенем спрямованості; ситуаиії вибору за мотиваиією досягнення мети. Простежено зв 'язок між розвитком креативних якостей особистості учнів підліткового віку і ситуачією вибору в навчально-музичній діяльності. Зроблено висновок, що більшість респондентів - підлітків $(52,6 \%)$ мають низький і нижче середнього рівні розвитку креативних особистісних якостей і характеризуються неприйняттям вибору в нестандартній ситуайї або пасивним до нього ставленням. 